REVIEWS

\title{
Current approaches to improve the anticancer chemotherapy with alkylating agents: state of the problem in world and Ukraine
}

\author{
A. P. Iatsyshyna \\ Institute of Molecular Biology and Genetics, NAS of Ukraine \\ 150, Akademika Zabolotnoho Str., Kyiv, Ukraine, 03680 \\ a.p.iatsyshyna@imbg.org.ua
}

\begin{abstract}
Alkylating agents are frequently used in many established anticancer chemotherapies. They alkylate the genomic DNA at various sites. Alkylation of the guanine at the $O^{6}$-position is cytotoxic, it has the strongest mutagenic potential, as well as can cause the tumor development. Alkyl groups at the $O^{6}$-position of guanine are removed by the DNA repair enzyme $O^{6}$-methylguanine-DNA methyltransferase (MGMT). The effectiveness of alkylating chemotherapy is limited by MGMT in cancer cells and adverse toxic side effects in normal cells. Different approaches consisting in the modulation of the MGMT expression and activity are under development now to improve the cancer chemotherapy. They include two main directions, in particular, the increase in chemosensitivity of cancer cells to alkylating drugs and the protection of normal cells from the toxic side effects of chemotherapy. This review is focused on current attempts to improve the alkylating chemotherapy of malignant tumours worldwide and state of the issue in Ukraine.
\end{abstract}

Keywords: cancer chemotherapy, strategies of chemotherapy improvement, alkylating agents, $O^{6}$-methylguanine-DNA methyltransferase (MGMT), DNA repair.

Introduction. Alkylating agents are frequently used in the anticancer chemotherapy. These agents alkylate the genomic DNA at various sites [1]. Alkylation of the guanine at the $\mathrm{O}^{6}$-position is cytotoxic, it has the strongest mutagenic potential as well as can cause the tumor development [1,2]. Different pathways of DNA repair are evolved in mammalian cells for self-defense against toxic and mutagenic effects, namely direct reversal repair, mismatch repair (MMR), nucleotide and base excision repair, as well as repair of double-strand DNA breaks and interstrand cross-links by homologous recombination and non-homologous end joining [3-5]. DNA adducts at the $\mathrm{O}^{6}$-position of guanine (such as methyl-, ethyl-, chloroethyl-group a. o.) of mammalian DNA are removed by the DNA repair enzyme $\mathrm{O}^{6}$-methylguanine-DNA methyltransferase (MGMT). This DNA repair enzyme belongs to the direct repair pathway, i. e. removes alkyl groups without DNA le-

(C) Institute of Molecular Biology and Genetics, NAS of Ukraine, 2012 sion, transferring them to an own cysteine residue by the mechanism of so-called «suicidal» reaction $[1,2]$. The capacity of cells to repair the $\mathrm{O}^{6}$-alkylguanine depends on the levels of expression and activity of MGMT in cell or on the rate at which a cell can synthesize this enzyme. Thus, the activity of this alkyltransferase is the most important factor of the cell sensibility to cytotoxic and mutagenic effects of the alkylation, but just MGMT is one of the causes of tumor cell resistance to specific alkylating agents of chemotherapeutic drugs. Therefore, the MGMT is considered as one of the molecular marker for the prediction of the efficiency of the chemotherapeutic treatment of cancer cells. Different approaches of consisting in the modulation of the MGMT expression and activity have been developing now to improve the efficacy of cancer chemotherapy by alkylating agents and to reduce its toxic side effects.

For example, the MGMT gene transcription silencing, RNA interference, and the MGMT enzyme inactivation are among strategies to increase the sensitivity of 
The alkylating agents used in the chemotherapy as anticancer drugs

\begin{tabular}{|c|c|c|c|c|}
\hline \multicolumn{3}{|c|}{ Classical alkylating agents } & \multirow{2}{*}{ Non-classical agents } & \multirow{2}{*}{$\begin{array}{l}\text { Alkylating-like agents } \\
\text { (platinum analogues)* }\end{array}$} \\
\hline Nitrogen mustards & Nitrosoureas & Alkyl sulfonates & & \\
\hline Cyclophosphamide & Methylating agents & Busulfan & Altretamine & Cisplatin \\
\hline Mechlorethamine (or mustine) & Dacarbazine (DTIC)* & - & - & Carboplatin \\
\hline Uramustine (or uracil mustard) & Procarbazine & - & - & Nedaplatin \\
\hline Melphalan & Streptozocin & - & - & Oxaliplatin \\
\hline Chlorambucil & Temozolomide (TMZ)* & - & - & Satraplatin \\
\hline Ifosfamide & Chloroethylating agents & - & - & Triplatin tetranitrate \\
\hline Thiotepa & Nimustine (ACNU) & - & - & - \\
\hline- & Carmustine (BCNU) & - & - & - \\
\hline- & Lomustine (CCNU) & - & - & - \\
\hline- & Semustine (MeCCNU) & - & - & - \\
\hline- & Fotemustine & - & - & - \\
\hline
\end{tabular}

*The platinum analogues, as well as the tetrazines (dacarbazine, temozolomide) are sometimes described as non-classical. The agents allowed to use in Ukraine are highlighted in bold $[4,5]$.

cancer cells to alkylating drugs, while the drug dose reduction, the local drug administration, and the myeloprotective gene therapy are used for the protection of bone marrow cells from these drugs.

This review is focused on current attempts to improve the alkylating chemotherapy of malignant tumours in the world and state of this issue in Ukraine.

Alkylating agents and cancer therapy. Alkylating agents are classified into several groups, namely into classical, non-classical and alkylating-like agents (Table). Among classical alkylating agents with true alkyl groups are nitrosoureas, which are often used in chemotherapy of brain tumors, because they have lipophilic properties and thus can cross the blood-brain barrier. Methylating and chloroethylating nitrosoureas have a strong cytotoxic effect on dividing cells causing the apoptotic cell death induced by the $\mathrm{O}^{6}$-alkylguanine, but the using of such type of medicine is non-effective in many cases because of the DNA repair by the MGMT enzyme.

A list of antineoplastic alkylating drugs approved for the use in Ukraine in therapy of different types of cancer by the order of Ministry of Health of Ukraine is given in the State form of medicines (\# 173, March 17, 2009). This list is based on the previous order of Minis- try of Health of Ukraine (\# 514, September 05, 2008), but contains some changes and the information about interaction with other medicines and some features of drug use, in particular, main pharmacotherapeutic effects, indications for the use, modes and doses, side effects and complications, contraindications etc. (\# 173, March 17, 2009). The medicines that are allowed for using in the cancer therapy in Ukraine are highlighted in bold in the Table.

Many established cancer therapies involve the DNA damage radiotherapy and/or chemotherapy, in which different alkylating agents are used alone or in combination with other agents as the antineoplastic drugs. They have the ability to alkylate many nucleophilic functional groups under conditions existing in the cells, chemically modifying the DNA, RNA and proteins, impairing in such way biologically important cell functions [1]. The alkylating agent effectiveness is limited by adverse toxic side effects for normal cells, which defines maximum tolerated doses, especially for the cells that propagate frequently, for example the cells of bone marrow, gastrointestinal tract, testicles and ovaries.

Another major clinical barrier for the successful anticancer therapy is the inherent or treatment-induced resistance of tumor cells to the chemotherapeutic agents. 
The effectiveness of antineoplastic agents is dependent not only on an appropriate choice of drugs at certain type of cancer and scheme of therapy, but also on different DNA repair systems. For example, as abovementioned, the MGMT can cause the resistance of cancer cells to alkylating agents via direct repair of the $\mathrm{O}^{6}$-alkylguanine. The effectiveness of anticancer therapy depends also on the activity of post-replication MMR system (in case of the methylating agents) or other systems of the DNA repair and recombination (in case of the chloroethylating agents) [1]. The resistance of cancer cells to alkylating agents can be caused also by repeated treatment with a drug. Such acquired resistance is frequently observed in tumor therapy, in particular in melanoma treatment with fotemustine [6], glioma - with temozolomide (TMZ) [7, 8]. It has been shown on the cell line models that the glioma cells, acquired resistance to TMZ, had at least two different mechanisms consistent with clinical observations, namely the $M G M T$ re-expression or MMR inactivation and the recruitment of key base excision repair enzymes [9]. For the extensive review on mechanisms of chemoresistance of malignant glioma cells see [10].

It has been observed that the $M G M T$ promoter methylation is correlated with a better outcome of alkylating agent therapy of malignant brain tumors and prolonged survival of patients [11] suggesting the $M G M T$ promoter methylation status is a predictive marker for clinical outcome in glioma therapy [12]. However, it has been revealed in clinical trial of TMZ in advanced malignant melanoma that pretreatment levels of MGMT in melanoma cells did not predict the clinical response to TMZ [13], assuming probably a higher frequency of reinactivation of the $M G M T$ expression in melanoma cells. Thus, MGMT is one of the most important factors of normal and cancer cell sensitivity and response to the alkylating drugs that can cause the chemoresistance.

The examination of the $M G M T$ promoter methylation status and/or the $M G M T$ expression level together with the p53 expression analysis in tumors are important steps in individual approach to the choice of alkylating agents and clinical protocols of the treatment of gliomas and malignant melanomas. As mentioned above, such approach is used in the chemotherapy of malignant brain tumors. However, this diagnostics, unfortunately, is not being carried out in Ukraine. Analysing the recom- mended schemes of the treatment of main cancer types in adults (\# 554, September 17, 2007 and \# 645, July 30, 2010) and children (\# 649, August 28, 2009 and \# 618, July 23,2010 ), it should be mentioned that for today in normative documents of Ministry of Health of Ukraine there is no a single recommendation for the analysis of the MGMT expression and/or methylation of its promoter. It is not considered even as an additional survey, which can be conducted at presence of the sufficient supply of materials and machinery or at patients cost at their desire, in valid for today normative documents of Ministry of Health of Ukraine.

Approaches to improve the chemotherapy of cancer. Taking into consideration the above outlined barriers of the to successful treatment of malignant tumors by alkylating agents, different approaches of the modulation of the $M G M T$ expression and the enzyme activity are developing now as possible strategies of the chemotherapy improvement. They include two main directions, in particular, the MGMT inactivation in cancer cells to increase the chemotherapy efficiency, and the MGMT activation in bone marrow cells or local drug administration to protect normal cells from the toxic effect of alkylation agents (Figure).

The increase in tumor cell sensitivity to alkylating drugs. Silencing of the MGMT gene (repression of the transcription), silencing of the MGMT protein biosynthesis (RNA interference), and the MGMT enzyme inactivation belong to strategies to increase the sensitivity of cancer cells to alkylating drugs (Figure).

The repression of the MGMT gene transcription can be achieved in different ways, for example by using transcription factors, epigenetic changes of the gene promoter region, the gene body or chromatin. However, it will be difficult to implement these approaches in clinic due to the lack of knowledge about the subtle mechanisms of transcription regulation of the $M G M T$ gene and consequences of their clinical use.

Oncolytic viruses possess an inherent tropism to tumour cells, so they are being investigated for selective replication in cancer cells and their destruction. Some academic labs and companies work with adenovirus or other viruses to study a viral therapy of cancer $[14,15]$. It has been shown that the $E 1 A$ gene product of adenovirus efficiently down-regulates $M G M T$ due to the prevention of p300 from the recruitment to the MGMT pro- 


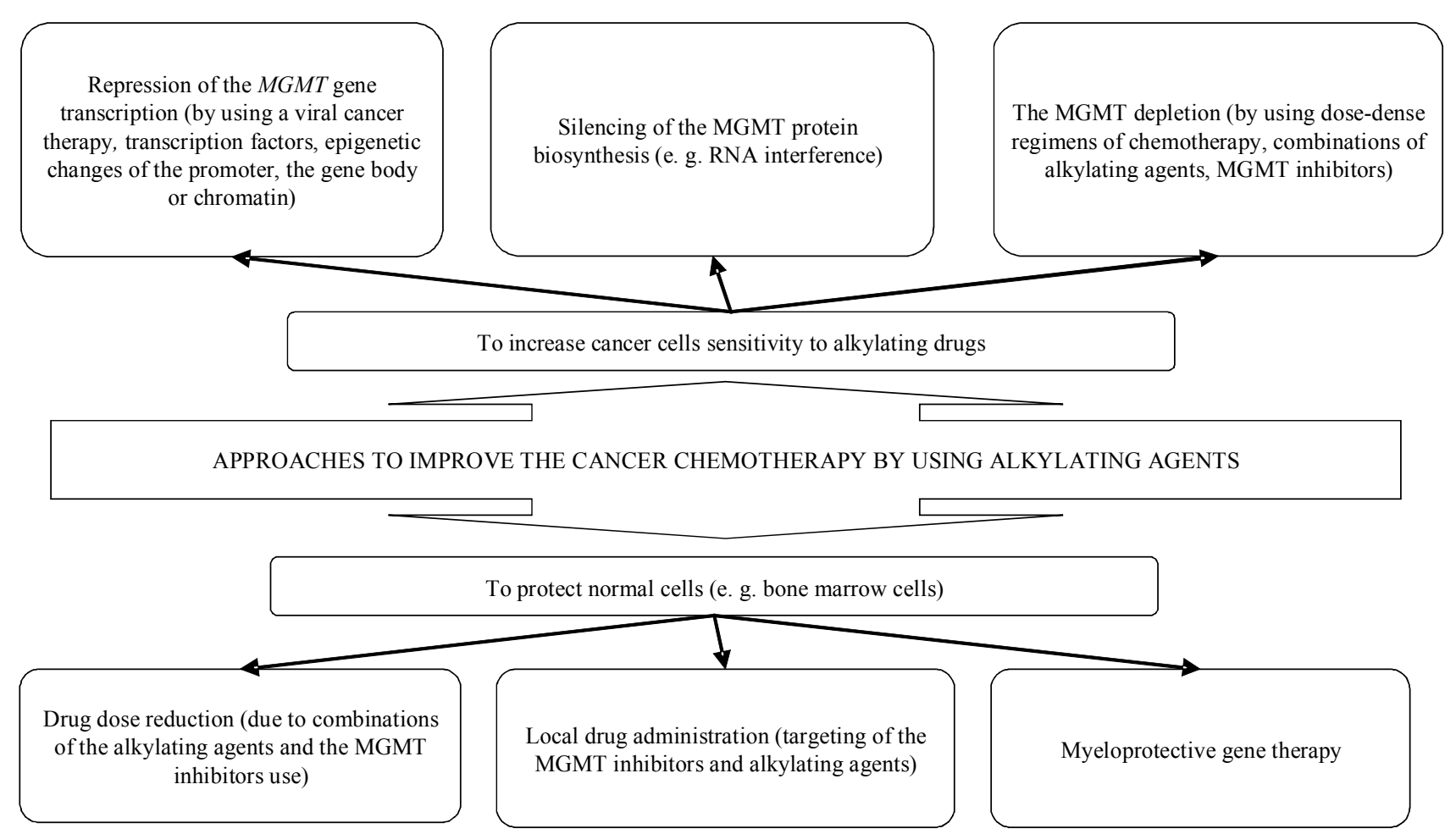

Different strategies of two main approaches to improve the cancer chemotherapy by using alkylating drugs

moter and may thus reduce chemoresistance, suggesting a possibility of the combined chemotherapy and viral therapy $[7,8]$. The first viral therapy of cancer in the world was approved for research in China several years ago and passed the phase I to phase III clinical trials for treating head and neck cancer $[14,16]$. Several recombinant vaccinia virus products for cancer therapy have been also developed by Jennerex Biotherapeutics Inc. company (USA).

In spite of up-and-coming prospects of viral therapies, the main obstacle is the human adaptive immune response and virulent strains that arised and did not dissapear during viral replication in tumours.

The RNA interference (RNAi) as a technology to silence gene expression can be also used to silence the $M G M T$ gene. It has been shown that transfection of in vitro cultivated cells with the MGMT-targeted shortinterfering RNA increased cell sensitivity to alkylating agents, for example human nasopharyngeal carcinoma HONE-1 cells to carmustine (BCNU) [17] and malignant glioma cells to TMZ [18]. It is suggested the clinical use of the RNAi strategy to sensitize cancer cells to the alkylating drugs. However, among significant problems, which prevent the in vivo RNAi application targe- ted to MGMT, are incomplete silencing of a target gene and so-called off-target effects, non-specific immune responses, and a major challenge - in vivo delivery.

The depletion of MGMT. The MGMT enzyme may be inactivated in two ways, namely by using the alkylating agents which inactivate this enzyme indirectly via the direct reversal DNA repair, as well directly by using the low-molecular MGMT inhibitors.

The dose-dense schedules of cancer chemotherapy and combinations of the alkylating agents have been studied as strategies to deplete the MGMT enzyme and increase cancer cell sensitivity to the chemotherapy. The dose-dense regimen was considered as one of the most important tools in the conventional chemotherapy of patients with potentially curable malignancies [19]. The data on efficacy, safety and toxic side effects of dose-dense TMZ regimens in patients with recurrent glioma and advanced metastatic melanoma are reviewed in [20]. A proper drug combination can also deplete MGMT. For example, it has been shown that methylating agents are able to reduce the MGMT activity prior to the administration of chloroethylating agents. However, the high-intensive chemotherapy causes the MGMT depletion not only in tumor cells, but also in 
normal cells, thus increasing toxic side effects, in particular myelosuppression and therapy-related secondary tumours (see below) [21].

The MGMT activity can be blocked by inhibitors of this enzyme, low molecular weight pseudosubstrates, used prior to the alkylating agent chemotherapy [22]. Among the MGMT inhibitors are analogues of the $\mathrm{O}^{6}$-methylguanine in DNA, namely the $\mathrm{O}^{6}$-benzylguanine $\left(\mathrm{O}^{6}\right.$-BG) and the $\mathrm{O}^{6}$-(4-bromothenyl)guanine (Lomeguatrib, LM, Patrin, PaTrin-2).

It has been shown in human tumour cell lines, xenograft models of different cancer types, as well as in clinical trials that inactivation of MGMT by the pseudosubstrate inhibitors sensitizes tumour cells to the alkylating and alkylating-like agents [23, 24]. The chemotherapy regimens of $\mathrm{O}^{6}-\mathrm{BG}$ in combination with $\mathrm{BCNU}$, TMZ and Gliadel ${ }^{\circledR}$ (wafer of polifeprosan 20 with $\mathrm{BCNU}$ ) are in clinical development.

Now, the Phases I and II of several clinical trials of the $\mathrm{O}^{6}$-BG and $\mathrm{BCNU}$ or TMZ combination are completed, and the Phases II and III are still ongoing in brain tumors, colon cancer, lymphoma, melanoma or sarcoma. For instance, the Phase I clinical trial of coadministration of $\mathrm{O}^{6}-\mathrm{BG}$ and $\mathrm{BCNU}$ was conducted in USA in the patients with advanced solid tumors (malignant gliomas, melanomas) and with lymphoma [25]. Also, the combination of a bolus injection of $\mathrm{O}^{6}$-BG with implanted Gliadel ${ }^{\circledR}$ wafers in adult patients with recurrent glioblastoma multiforme improved the efficacy of implanted Gliadel $^{\circledR}$ wafers in the Phase II trial [26]. In another Phase II clinical trial, the coadministration of $\mathrm{O}^{6}$-BG with TMZ has been studied in the patients with progressive malignant glioma (USA) [27]. Though the use of $\mathrm{O}^{6}$-BG gave a possibility to reduce a dose of alkylating drug, it causes primary bone marrow suppression which may be cumulative in the combination with alkylating drug, so other pseudosubstrates of the MGMT enzyme are currently being developed and investigated.

LM is another MGMT pseudosubstrate, which is less toxic and more potent inactivator of this enzyme, than $\mathrm{O}^{6}$-BG. The inhibitory activity of LM has been shown in preclinical studies, in particular in human primary cells, tumor cell lines and xenograft models including breast tumors [28], acute leukaemia [29], melanoma [30], ovarian cancer [31], as well as in clinical trials.
The Phase I clinical trials of combined TMZ and LM treatment of the patients with melanoma conducted at Christie Hospital and at University College have been completed (London, U. K.) [32] and now the Phase II trials are ongoing. Also, there was conducted another randomized trial of the LM-TMZ combination in chemotherapy of the patients with metastatic unresectable stage III or IV cutaneous melanoma [33].

The LM-TMZ combination in treatment of patients with inoperable stage IV metastatic colorectal carcinoma has been shown to be inefficient in a multi-centre Phase II clinical trial conducted in U. K. (Christie and Churchill Hospitals) and Australia (8 centres) [34]. However, the therapy of patients with metastatic colorectal cancer using a combination of LM and irinotecan (the Phase I trial) was more successful [35]. No advantage of the combined therapy by LM-TMZ over conventional TMZ administration has been also observed in the Phase I study melanoma treatment in the patients with advanced unresectable stage III or IV cutaneous or unknown primary melanoma metastases [36].

LM is also being trialled in USA in combination with dacarbazine for melanoma and in Italy in combination with TMZ for leukaemia treatment (data on website of Carcinogenesis group, Paterson Institute for Cancer Research, The University of Manchester, U. K.).

However, it has been revealed that the systemic administration of $\mathrm{O}^{6}$-BG-based inhibitors of MGMT and their combination with alkylating agents causes depletion of MGMT in all tissues of the body enhancing the cytotoxicity and the induction of GC to AT transition mutations presumably in stem cells, so the strategies to protect normal cells during the cancer chemotherapy are also being investigated.

The reduction of toxic side effects of alkylating drugs. It is known that the alkylating agents have toxic side effects in normal cells that divide frequently. These agents can cause secondary tumors, for example, leukemia. Their carcinogenic role has been shown in animal models, as well in clinical studies [21]. The acute myeloid leukemia is the most frequent late complication of the alkylating agent chemotherapy and/or radiotherapy, as well as the chemotherapy with topoisomerase-II-inhibitors and antimetabolites [21, 37]. Thus, a decrease in a toxic side effect of drugs is an important task in cancer therapy. Drug dose reduction, local drug 
administration, and myeloprotective gene therapy are among the strategies of the protection of bone marrow cells from alkylating drugs (Figure).

The dose reduction of alkylating drugs can be achieved by coadministration with the MGMT inhibitors. For more details see above «The depletion of the MGMT».

In the strategy of the local drug administration an alkylating agent alone or in combination with the MGMT inhibitor, for example $\mathrm{O}^{6}-\mathrm{BG}$, is administered directly into the tumour area to reduce the drug toxicity to the organism. Several approaches to melanoma therapy have been developed in animal model and studied in clinic. It has been shown in a rat model that the concomitant application of hyperthermia during an isolated limb infusion of TMZ has improved the efficacy of melanoma therapy [38]. A significant improvement of melanoma antitumor responses with a tumour growth delay and minimal toxicity has been also shown in another study of regional therapy of human melanoma xenografts of the extremity in nude rats by using parenteral TMZ administration in conjunction with $\mathrm{O}^{6}$-BG [39]. In the same animal model it has been shown that therapy with a regional infusion of TMZ was more effective for the xenograft with the lowest MGMT activity than melphalan which was more effective at the highest MGMT activity [40].

To optimize the response of recurrent melanoma of human extremity and to minimize drug toxicity to normal cells it has been used a regional therapy with two procedures, namely hyperthermic isolated limb perfusion and isolated limb infusion [41]. This therapy provides a way to deliver a chemotherapy drug locally to extremity in a higher dose.

The local administration of alkylating drug into the area after tumour resection in combination with a systemic infusion of $\mathrm{O}^{6}-\mathrm{BG}[42,26]$ and the intracerebral administration of $\mathrm{O}^{6}$-BG combined with systemic chemotherapy with TMZ [43] are new strategies of the local brain tumour therapy. In the Phase I trial held in USA the optimal dose of $\mathrm{O}^{6}$-BG coadministered intravenously as a continuous infusion with intracranially implanted Gliadel ${ }^{\circledR}$ wafers has been studied in adult patients with recurrent malignant glioma [42]. In the Phase II trial of Gliadel ${ }^{\circledR}$ wafers it has been shown that a systemic administration of $\mathrm{O}^{6}$-BG can have side effects, among which an increased risk of hydrocephalus, cere- brospinal fluid leak, and cerebrospinal fluid/brain infection despite the therapy efficacy improvement [26]. In another study of systemic chemotherapy of recurrent glioblastoma with TMZ, local MGMT inactivation has been achieved by the intracerebral administration of $\mathrm{O}^{6}$-BG in the tumour cavity [43]. It has been shown that this strategy might be safe for improving glioma therapy without increasing drug-induced systemic toxic side effects.

Different strategies of the myeloprotective gene therapy have been studied to increase the level of the MGMT expression in peripheral mononuclear blood cells [44]. Among them is the ex vivo transduction of hematopoietic stem cells transfected by the vectors expressing mutant forms of the MGMT protein coupled with the simultaneous use of pharmacologic MGMT inhibitors and alkylating drugs [44, 45]. Such mutant MGMT proteins (e. g. G156A, P140K) are resistant to the inactivation by pseudosubstrates, such as $\mathrm{O}^{6}-\mathrm{BG}$, LM. This innovative approach in the cancer chemotherapy has a main goal to protect hematopoietic cells and enhance the DNA repair activity by stably integrating gene vectors that express $M G M T$. Therefore, the potent expression cassettes have been designed which can be used as potentially useful in the clinic MGMT vectors, an important component of which is formed by active enhancer sequences. However, it has been revealed that the vectors with strong enhancers are more likely to induce adverse events related to insertional mutagenesis [45]. Also, it is suggested that in the absence of alkylating agents high expression of the P140K mutant can induce a selective disadvantage. Considering these observations, now the attempts to generate clinically useful and safe MGMT vectors have being done.

The defence of bone marrow-derived hematopoietic progenitors from toxic side effects of the chemotherapeutic alkylating drugs (for example BCNU or TMZ) and $\mathrm{O}^{6}-\mathrm{BG}$ by using oncoretroviral transduction of the mutant form of $\mathrm{MGMT}^{\mathrm{G} 156 \mathrm{~A}}$ into mouse and human hematopoietic progenitors has been presented in early papers devoted to the myeloprotective gene therapy [4648]. However, it has been shown that hematopoietic stem cells expressing the P140K mutant form of MGMT were more $\mathrm{O}^{6}$-BG-resistant under stringent drug-selection competition than the G156A [49]. So, the papers about the mouse model of transplantation of hemato- 
poietic stem cells transfected by vectors expressing the P140K appeared a few years later [50, 51]. It has been found that the retroviral co-expression of the P140K with either p-glycoprotein or multidrug resistance-related protein 1 may provide an effective in vivo protection of hematopoietic cells during the cancer chemotherapy [52]. An increased protective effect of the simultaneous overexpression of the multidrug resistance-related protein 1 and the $\mathrm{P} 140 \mathrm{~K}$ has been also shown in a more recent study [53]. A bicistronic lentiviral vector overexpressing these two drug-resistance genes provided the protection of leukemia cell line HL60 against $\mathrm{O}^{6}$-BG and nimustine (ACNU) plus paclitaxel therapy as well as the protection of human hematopoietic $\mathrm{CD}^{+} 4^{+}$stem cells against both monotherapy with $\mathrm{O}^{6}$ BG-TMZ and combined therapy with $\mathrm{O}^{6}$-BG-TMZ plus paclitaxel.

Since self-inactivating retroviral vectors lacking enhancer-promoter sequences in the long terminal repeats were related to insertional mutagenesis, it has been studied the potency of gammaretroviral and lentiviral vectors expressing the $\mathrm{P} 140 \mathrm{~K}$ mutant under control of enhancer-promoter sequences located either in the long terminal repeat or downstream of the packaging region to internal initiation of transcription from self-inactivating backbones [54]. It has been revealed that gammaretroviral vectors with intact long terminal repeats containing enhancer-promoter sequences showed both higher titres and higher expression levels than the lentiviral counterparts, as well as a higher transduction efficiency on proliferating human $\mathrm{CD} 34^{+}$cells [54]. The potential utility of lentiviral vectors for the drug-resistant gene transfer to human hematopoietic stem cells for in vivo selection and marrow protection has been studied because of their enhanced ability to transduce nondividing cells [55]. The use of the $\mathrm{P} 140 \mathrm{~K}$ provided efficient post-transduction selection of human cells using lentivirus under low-multiplicity of infection conditions that did not require cytokine stimulation or viral concentration, and the therapeutic drug combination of $\mathrm{BCNU}$ and $\mathrm{O}^{6}$-BG [55].

Besides, it has been shown a possibility to transfer the $\mathrm{P} 140 \mathrm{~K}$ into long-term repopulating hematopoietic stem cells by using foamy virus, because such systems may integrate in the positions that modulate host gene expression to a less extent than oncoretroviral or len- tiviral vectors [56]. The expression of $\mathrm{P} 140 \mathrm{~K}$ under control of weaker promoter/enhancers in gammaretroviral vectors sufficient for in vivo protection and selection of the transduced mouse bone marrow cells following the treatment with $\mathrm{O}^{6}-\mathrm{BG}$ and $\mathrm{TMZ}$ has been also studied to avoid insertional mutagenesis and other consequences caused by strong enhancer elements [57].

The human mutant form of $\mathrm{MGMT}^{\mathrm{P} 140 \mathrm{~K}}$ is also used in other gene therapies to increase the percentage of gene-modified cells after transplantation, for example in anti-retroviral therapy of human immunodeficiency virus infection [58].

The data obtained in mice encourage further investigations in large animal models and clinical trials. Thus, gene transfer of the mutant MGMT (e. g. P140K) into hematopoietic stem cells provides a mechanism for the alkylating drug resistance and the selective expansion of gene-modified cells in vivo. A possible clinical application of this myeloprotective gene strategy is chemoprotection that allows a dose escalation of the alkylating chemotherapy.

Unfortunately, at the moment the abovementioned strategies are not in clinical trials in Ukraine, except for dose-dense regimens of the cancer chemotherapy and combinations of alkylating agents. Hopefully, this review will stimulate the scientists in Ukraine to study the problem of improvement of the cancer chemotherapy by using the alkylating agents.

Conclusions. The alkylating agents are frequently used in the cancer chemotherapy, so the relative level of expression of the DNA repair enzyme MGMT, which repairs the $\mathrm{O}^{6}$-alkylguanine caused by these agents, in tumor cells may determine the response to these drugs. The modulation of the MGMT expression and activity in tumor and normal cells is currently being investigated to improve the cancer therapy by using the alkylating agents. Two main approaches to the improvement of such chemotherapy are discussed in the review. The first one is an increase in the efficiency of cancer chemotherapy due to the MGMT inactivation. The MGMT gene transcription repression, RNA interference, and the MGMT enzyme activity depletion by using the dose-dense cytotoxic chemotherapy drug schedule, a combination of alkylating agents with/or without pseudosubstrate inhibitors of MGMT are the strategies of this approach. The second approach has been developed to 
protect normal cells from the toxic effect of the alkylating drugs. It also includes several strategies, namely the drug dose reduction, the local drug administration and the myeloprotective gene therapy, which implies the MGMT activation in bone marrow hematopoietic cells.

The results of preclinical and clinical researches involving various aspects of the MGMT modulation could provide prospects for therapy of melanoma, glioma and other cancer types irresponsive to the alkylating agents. A variety of strategies for improving the cancer therapy have been studied in clinical trials in different countries. Further studies are needed for successful clinical use of developed strategies, and especially at least the MGMT expression analysis during the choice of alkylating drugs and therapy scheme for the patients with aggressive malignant tumours.

\section{А. П. Яиишина}

Сучасні підходи до покращеня протипухлинної хіміотерапії з використанням алкілувальних сполук: стан проблеми в світі та в Україні

\section{Резюме}

Алкілувальні сполуки часто застосовують у хіміотерапії раку. Вони алкілують геномну ДНК по багатьох сайтах. Алкілування гуаніну в позиції $O^{6}$ иитотоксичне, має найсильніший мутагенний потенціал, а також може спричиняти розвиток вторинних пухлин. Алкільні групи у позичї $O^{6}$ гуаніну видаляються за допомогою репаративного ферменту $O^{6}$-метилгуанін-ДНК метилтрансферази (MGMT). Ефективність хіміотерапії з використанням $O^{6}$ алкілувальних сполук обмежена експресією MGMT у ракових клітинах та шкідливим побічним токсичним впливом у нормальних клітинах. Наразі для покращення хіміотерапії раку розробляють різні підходи до модулячії експресії та активності MGMT. До них належать два головних напрямки, а саме - підвищення хіміочутливості ракових клітин до алкілувальних ліків $і$ захист нормальних клітин від токсичної дії хіміотерапії. Огляд зосереджено на існуючих спробах покращити хіміотерапію злоякісних пухлин за допомогою алкілувальних сполук як у світі, так і в Україні.

Ключові слова: хіміотерапія раку, стратегії покращення хіміотерапії, алкілувальні сполуки, $O^{6}$-метилгуанін-ДНК метилтрансфераза (MGMT), репарація ДНК.

\section{А. П. Яиышина}

Современные подходы к улучшению противоопухолевой химиотерапии с использованием алкилирующих соединений: состояние проблемы в мире и в Украине

\section{Резюме}

Алкилирующие соединения часто применяют в химиотерапии рака. Они алкилируют геномную ДНК по многим сайтам. Алкилирование гуанина в позищии $O^{6}$ циитотоксично, имеет сильнейший мутагенный потенциал и может приводить к развитию вторичных опухолей. Алкильные группы в позиции $O^{6}$ гуанина удаляются с помощьью репаративного фермента $O^{6}$-метилгуанин-ДНК метилтрансферазы (MGMT). Эффективность химиотерапии с использованием $O^{6}$-алкилирующих соединений ограничена экспрессией MGMT в опухолевых клетках и неблагоприятным побочным токсическим действием в нормальных клетках. В настоящее время для улучшения химиотерапии рака разрабатываются разные подходы к модуляции экспрессии и активности MGMT. К ним принадлежат два основных направления, а именно - увеличение химиочувствительности раковых клеток к алкилирующим лекарствам и защита нормальных клеток от побочного влияния химиотерапии. Обзор сосредоточен на существуюших попьтках улучшить химиотерапию злокачественных опухолей с помощью алкилирующих соединений как в мире, так и в Украине.

Ключевые слова: химиотерапия рака, стратегии улучшения химиотерапии, алкилирующие соединения, ${ }^{6}$-метилгуанин-ДНК метилтрансфераза (MGMT), репарация ДНК.

\section{REFERENCES}

1. Kaina B., Christmann M., Naumann S., Roos W. P. MGMT: key node in the battle against genotoxicity, carcinogenicity and apoptosis induced by alkylating agents // DNA Repair (Amst).2007.-6, N 8.-P. 1079-1099.

2. Verbeek B., Southgate T. D., Gilham D. E., Margison G. P. O 6 Methylguanine-DNA methyltransferase inactivation and chemotherapy // Br. Med. Bull.-2008.-85, N 1.-P. 17-33.

3. Hansen $W$. K., Kelley M. R. Review of mammalian DNA repair and translational implications // J. Pharmacol. Exp. Ther.-2000.295, N 1.-P. 1-9.

4. Christmann M., Tomicic M. T., Roos W. P., Kaina B. Mechanisms of human DNA repair: an update // Toxicology.-2003.-193, N 1-2.-P. 3-34.

5. Scharer O. D. Chemistry and biology of DNA repair// Angew. Chem. Int. Ed. Engl.-2003.-42, N 26.-P. 2946-2974.

6. Christmann M., Pick M., Lage H., SchadendorfD., Kaina B. Acquired resistance of melanoma cells to the antineoplastic agent fotemustine is caused by reactivation of the DNA repair gene MGMT // Int. J. Cancer.-2001.-92, N 1.-P. 123-129.

7. Jiang H., Alonso M. M., Gomez-Manzano C., Piao Y., Fueyo J. Oncolytic viruses and DNA-repair machinery: overcoming chemo resistance of gliomas // Expert Rev. Anticancer Ther.-2006.6, N 11.-P. 1585-1592.

8. Alonso M. M., Gomez-Manzano C., Bekele B. N., Yung W. K., Fueyo $J$. Adenovirus-based strategies overcome temozolomide resistance by silencing the $\mathrm{O}^{6}$-methylguanine-DNA methyltransferase promoter // Cancer Res.-2007.-67, N 24.-P. 11499-11504.

9. Zhang J., Stevens M. F., Laughton C. A., Madhusudan S., Bradshaw T. D. Acquired resistance to temozolomide in glioma cell lines: molecular mechanisms and potential translational applications // Oncology.-2010.-78, N 2.-P. 103-114.

10. Sarkaria J. N., Kitange G. J., James C. D., Plummer R., Calvert H., Weller M., Wick W. Mechanisms of chemoresistance to alkylating agents in malignant glioma // Clin. Cancer Res.-2008.14, N 10.-P. 2900-2908.

11. Hegi M. E., Diserens A. C., Gorlia T., Hamou M. F., de Tribolet N., Weller M., Kros J. M., Hainfellner J. A., Mason W., Mariani L., Bromberg J. E., Hau P., Mirimanoff R. O., Cairncross J. G., Janzer R. C., Stupp R. MGMT gene silencing and benefit from temozolomide in glioblastoma // N. Engl. J. Med.-2005.-352, N 10.-P. 997-1003.

12. Riemenschneider M. J., Hegi M. E., Reifenberger G. MGMT promoter methylation in malignant gliomas // Target Oncol.2010.-5, N 3.-P. 161-165. 
13. Soejima H., Zhao W., Mukai T. Epigenetic silencing of the $M G M T$ gene in cancer // Biochem. Cell Biol.-2005-83, N 4.P. 429-437.

14. Garber $K$. China approves world's first oncolytic virus therapy for cancer treatment // J. Natl Cancer Inst.-2006.-98, N 5.P. $298-300$

15. Kumar S., Gao L., Yeagy B., Reid T. Virus combinations and chemotherapy for the treatment of human cancers // Curr. Opin. Mol. Ther.-2008.-10, N 4.-P. 371-379.

16. $Y u W$., Fang $H$. Clinical trials with oncolytic adenovirus in China // Curr. Cancer Drug Targets.-2007.-7, N 2.-P. 141148 .

17. Кио C. C., Liu J. F., Chang J. Y. DNA repair enzyme, $\mathrm{O}^{6}$-methylguanine DNA methyltransferase, modulates cytotoxicity of camptothecin-derived topoisomerase I inhibitors // J. Pharmacol. Exp. Ther.-2006.-316, N 2.-P. 946-954.

18. Kato T., Natsume A., Toda H., Iwamizu H., Sugita T., Hachisu R., Watanabe R., Yuki K., Motomura K., Bankiewicz K., Wakabayashi $T$. Efficient delivery of liposome-mediated MGMTsiRNA reinforces the cytotoxity of temozolomide in GBM-initiating cells // Gene Ther.-2010.-17, N 11.-P. 1363-1371.

19. Lyman G. H. Impact of chemotherapy dose intensity on cancer patient outcomes // J. Natl Compr. Canc. Netw.-2009.-7, N 1.P. 99-108.

20. Neyns B., Tosoni A., Hwu W. J., Reardon D. A. Dose-dense temozolomide regimens: antitumor activity, toxicity, and immunomodulatory effects // Cancer.-2010.-116, N 12.-P. 2868-2877.

21. Sill H., Olipitz W., Zebisch A., Schulz E., Wolfler A. Therapy-related myeloid neoplasms: pathobiology and clinical characteristics // Br. J. Pharmacol.-2011.-162, N 4.-P. 792-805.

22. McMurry T. B. MGMT inhibitors - the Trinity College-Paterson Institute experience, a chemist's perception // DNA Repair (Amst).- 2007.-6, N 8.-P. 1161-1169.

23. Middleton M. R., Margison G. P. Improvement of chemotherapy efficacy by inactivation of a DNA-repair pathway // Lancet Oncol.-2003.-4, N 1.-P. 37-44.

24. Kaina B., Margison G. P., Christmann M. Targeting $\mathrm{O}^{6}$-methylguanine-DNA methyltransferase with specific inhibitors as a strategy in cancer therapy // Cell. Mol. Life Sci.-2010.-67, N 21.P. 3663-3681.

25. Schilsky R. L., Dolan M.E., Bertucci D., Ewesuedo R. B., Vogelzang N. J., Mani S., Wilson L. R., Ratain M. J. Phase I clinical and pharmacological study of $\mathrm{O}^{6}$-benzylguanine followed by carmustine in patients with advanced cancer // Clin. Cancer Res.2000.-6, N 8.-P. 3025-3031.

26. Quinn J. A., Jiang S. X., Carter J., Reardon D. A., Desjardins A., Vredenburgh J. J., Rich J. N., Gururangan S., Friedman A. H., Bigner D. D., Sampson J. H., McLendon R. E., Herndon J. E. II, Threatt S., Friedman H. S. Phase II trial of Gliadel plus $\mathrm{O}^{6}$-benzylguanine in adults with recurrent glioblastoma multiforme // Clin. Cancer Res.-2009.-15, N 3.-P. 1064-1068.

27. Quinn J. A., Desjardins A., Weingart J., Brem H., Dolan M. E., Delaney S. M., Vredenburgh J., Rich J., Friedman A. H., Reardon D. A., Sampson J. H., Pegg A. E., Moschel R. C., Birch R., McLendon R. E., Provenzale J. M., Gururangan S., Dancey J. E., Maxwell J., Tourt-Uhlig S., Herndon J. E. II, Bigner D. D., Friedman H. S. Phase I trial of temozolomide plus $\mathrm{O}^{6}$-benzylguanine for patients with recurrent or progressive malignant glioma // J. Clin. Oncol.-2005.-23, N 28.-P. 7178-7187.

28. Clemons M., Kelly J., Watson A. J., Howell A., McElhinney R. S., McMurry T. B., Margison G. P. O $\mathrm{O}^{6}$-(4-bromothenyl)guanine reverses temozolomide resistance in human breast tumour MCF7 cells and xenografts // Br. J. Cancer.-2005.-93, N 10.P. 1152-1156.
29. Turriziani M., Caporaso P., Bonmassar L., Buccisano F., Amadori S., Venditti A., Cantonetti M., D'Atri S., Bonmassar E. O' ${ }^{6}$ (4-bromothenyl)guanine (PaTrin-2), a novel inhibitor of $\mathrm{O}^{6}$-alkylguanine DNA alkyl-transferase, increases the inhibitory activity of temozolomide against human acute leukaemia cells in vitro // Pharmacol. Res.-2006.-53, N 4.-P. 317-323.

30. Middleton M. R., Kelly J., Thatcher N., Donnelly D. J., McElhinney R. S., McMurry T. B. H., McCormick J. E., Margison G. $P$. $\mathrm{O}^{6}$-(4-bromothenyl)guanine improves the therapeutic index of temozolomide against A375M melanoma xenografts // Int. J. Cancer.-2000.-85, N 2.-P. 248-252.

31. Barvaux V. A., Lorigan P., Ranson M., Gillum A. M., McElhinney R. S., McMurry T. B., Margison G. P. Sensitization of a human ovarian cancer cell line to temozolomide by simultaneous attenuation of the Bcl-2 antiapoptotic protein and DNA repair by $\mathrm{O}^{6}$-alkylguanine-DNA alkyltransferase // Mol. Cancer Ther.2004.-3, N 10.-P. 1215-1220.

32. Ranson M., Middleton M. R., Bridgewater J., Lee S. M., Dawson M., Jowle D., Halbert G., Waller S., McGrath H., Gumbrell L., McElhinney R. S., Donnelly D., McMurry T. B., Margison G. P. Lomeguatrib, a potent inhibitor of $\mathrm{O}^{6}$-alkylguanine-DNA-alkyltransferase: phase I safety, pharmacodynamic, and pharmacokinetic trial and evaluation in combination with temozolomide in patients with advanced solid tumors // Clin. Cancer Res.-2006.12, N 5.-P. 1577-1584.

33. Ranson M., Hersey P., Thompson D., Beith J., McArthur G. A., Haydon A., Davis I. D., Kefford R. F., Mortimer P., Harris P. A., Baka S., Seebaran A., Sabharwal A., Watson A. J., Margison G. P., Middleton M. R. Randomized trial of the combination of lomeguatrib and temozolomide compared with temozolomide alone in chemotherapy naive patients with metastatic cutaneous melanoma // J. Clin. Oncol.-2007.-25, N 18.-P. 2540-2545.

34. Khan O. A., Ranson M., Michael M., Olver I., Levitt N. C., Mortimer P., Watson A. J., Margison G. P., Midgley R., Middleton $M$. R. A phase II trial of lomeguatrib and temozolomide in metastatic colorectal cancer // Br. J. Cancer.-2008.-98, N 10.P. $1614-1618$

35. Sabharwal A., Corrie P. G., Midgley R. S., Palmer C., Brady J., Mortimer P., Watson A. J., Margison G. P., Middleton M. R. A phase I trial of lomeguatrib and irinotecan in metastatic colorectal cancer // Cancer Chemother. Pharmacol.-2010.-66, N 5.P. 829-835.

36. Kefford R. F., Thomas N. P., Corrie P. G., Palmer C., Abdi E., Kotasek D., Beith J., Ranson M., Mortimer P., Watson A. J., Margison G. P., Middleton M. R. A phase I study of extended dosing with lomeguatrib with temozolomide in patients with advanced melanoma // Br. J. Cancer.-2009.-100, N 8.P. $1245-1249$

37. Leone G., Pagano L., Ben-Yehuda D., Voso M. T. Therapy-related leukemia and myelodysplasia: susceptibility and incidence // Haematologica.-2007.-92, N 10.-P. 1389-1398.

38. Ko S. H., Ueno T., Yoshimoto Y., Yoo J. S., Abdel-Wahab O. I., Abdel-Wahab Z., Chu E., Pruitt S. K., Friedman H. S., Dewhirst $M$. W., Tyler D. S. Optimizing a novel regional chemotherapeutic agent against melanoma: hyperthermia-induced enhancement of temozolomide cytotoxicity // Clin. Cancer Res.-2006.12, N 1.-P. 289-297.

39. Ueno T., Ko S. H., Grubbs E., Yoshimoto Y., Augustine C., Abdel-Wahab Z., Cheng T. Y., Abdel-Wahab O. I., Pruitt S. K., Friedman H. S., Tyler D. S. Modulation of chemotherapy resistance in regional therapy: a novel therapeutic approach to advanced extremity melanoma using intra-arterial temozolomide in combination with systemic $\mathrm{O}^{6}$-benzylguanine // Mol. Cancer Ther.-2006.-5, N 3.-P. 732-738. 
40. Yoshimoto Y., Augustine C. K., Yoo J. S., Zipfel P. A., Selim M. A., Pruitt S. K., Friedman H. S., Ali-Osman F., Tyler D. S. Defining regional infusion treatment strategies for extremity melanoma: comparative analysis of melphalan and temozolomide as regional chemotherapeutic agents // Mol. Cancer Ther.-2007.6, N 5.-P. 1492-1500.

41. Coleman A., Augustine C. K., Beasley G., Sanders G., Tyler D. Optimizing regional infusion treatment strategies for melanoma of the extremities // Expert Rev. Anticancer Ther.-2009.-9, N 11.-P. 1599-1609.

42. Weingart J., Grossman S. A., Carson K. A., Fisher J. D., Delaney S. M., Rosenblum M. L., Olivi A., Judy K., Tatter S. B., Dolan $M$. E. Phase I trial of polifeprosan 20 with carmustine implant plus continuous infusion of intravenous $\mathrm{O}^{6}$-benzylguanine in adults with recurrent malignant glioma: new approaches to brain tumor therapy CNS consortium trial // J. Clin. Oncol.2007.-25, N 4.-P. 399-404.

43. Koch D., Hundsberger T., Boor S., Kaina B. Local intracerebral administration of $\mathrm{O}^{6}$-benzylguanine combined with systemic chemotherapy with temozolomide of a patient suffering from a recurrent glioblastoma // J. Neurooncol.-2007.-82, N 1.-P. 85-89.

44. Milsom M. D., Williams D. A. Live and let die: in vivo selection of gene-modified hematopoietic stem cells via MGMT-mediated chemoprotection // DNA Repair (Amst). 2007.-6, N 8.P. 1210-1221.

45. Schambach A., Baum C. Vector design for expression of $\mathrm{O}^{6}$-methylguanine-DNA methyltransferase in hematopoietic cells // DNA Repair (Amst).-2007.-6, N 8.-P. 1187-1196.

46. Davis B. M., Reese J. S., Koc O. N., Lee K., Schupp J. E., Gerson $S$. L. Selection for G156A O ${ }^{6}$-methylguanine DNA methyltransferase gene-transduced hematopoietic progenitors and protection from lethality in mice treated with $\mathrm{O}^{6}$-benzylguanine and 1,3-bis(2-chloroethyl)-1-nitrosourea // Cancer Res.-1997.-57, N 22.-P. 5093-5099.

47. Reese J. S., Davis B. M., Liu L., Gerson S. L. Simultaneous protection of G156A methylguanine DNA methyltransferase genetransduced hematopoietic progenitors and sensitization of tumor cells using $\mathrm{O}^{6}$-benzylguanine and temozolomide // Clin. Cancer Res.-1999.-5, N 1.-P. 163-169.

48. Davis B. M., Reese J. S., Lingas K., Gerson S. L. Drug selection of mutant methylguanine methyltransferase from different oncoretroviral backbones results in multilineage hematopoietic transgene expression in primary and secondary recipients // J. Hematother. Stem Cell Res.-2003.-12, N 4.-P. 375-387.

49. Bowman J. E., Reese J. S., Lingas K. T., Gerson S. L. Myeloablation is not required to select and maintain expression of the drug-resistance gene, mutant MGMT, in primary and secondary recipients // Mol. Ther.-2003.-8, N 1.-P. 42-50.
50. Kramer B. A., Lemckert F. A., Alexander I. E., Gunning P. W. McCowage G. B. Characterisation of a $\mathrm{P} 140 \mathrm{~K}$ mutant $\mathrm{O}^{6}-\mathrm{me}-$ thylguanine-DNA-methyltransferase (MGMT)-expressing transgenic mouse line with drug-selectable bone marrow // J. Gene Med.-2006.-8, N 9.-P. 1071-1085.

51. Cai S., Hatwell J. R., Cooper R. J., Juliar B. E., Kreklau E., Abonour R., Goebel W. S., Pollok K. E. In vivo effects of myeloablative alkylator therapy on survival and differentiation of MGMTP140K-transduced human G-CSF-mobilized peripheral blood cells // Mol. Ther.-2006.-13, N 5.-P. 1016-1026.

52. Southgate T. D., Garside E., Margison G. P., Fairbairn L. J. Dual agent chemoprotection by retroviral co-expression of either MDR1 or MRP1 with the P140K mutant of $\mathrm{O}^{6}$-methylguanineDNA-methyl transferase // J. Gene Med.-2006.-8, N 8.P. 972-979.

53. Maier P., Spier I., Laufs S., Veldwijk M. R., Fruehauf S., Wenz $F$., Zeller $W$. J. Chemoprotection of human hematopoietic stem cells by simultaneous lentiviral overexpression of multidrug resistance 1 and $\mathrm{O}^{6}$-methylguanine-DNA methyltransferase $(\mathrm{P} 140 \mathrm{~K})$ // Gene Ther.-2010.-17, N 3.-P. 389-399.

54. Schambach A., Bohne J., Chandra S., Will E., Margison G.P., Williams D. A., Baum C. Equal potency of gammaretroviral and lentiviral SIN vectors for expression of $\mathrm{O}^{6}$-methylguanine-DNA methyltransferase in hematopoietic cells // Mol. Ther.-2006.13, N 2.-P. 391-400.

55. Zielske S. P., Lingas K. T., Li Y., Gerson S. L. Limited lentiviral transgene expression with increasing copy number in an MGMT selection model: lack of copy number selection by drug treatment // Mol. Ther.-2004.-9, N 6.-P. 923-931.

56. Cai S., Ernstberger A., Wang H., Bailey B. J., Hartwell J. R., Sinn A. L., Eckermann O., Linka Y., Goebel W. S., Hanenberg H., Pollok K. E. In vivo selection of hematopoietic stem cells transduced at a low multiplicity-of-infection with a foamy viral MGMT (P140K) vector // Exp. Hematol.-2008.-36, N 3.P. 283-292.

57. Milsom M. D., Jerabek-Willemsen M., Harris C. E., Schambach A., Broun E., Bailey J., Jansen M., Schleimer D., Nattamai K., Wilhelm J., Watson A., Geiger H., Margison G. P., Moritz T., Baum C., Thomale J., Williams D. A. Reciprocal relationship between $\mathrm{O}^{6}$-methylguanine-DNA methyltransferase P140K expression level and chemoprotection of hematopoietic stem cells // Cancer Res.-2008.-68, N 15.-P. 6171-6180.

58. Kiem H. P., Wu R. A., Sun G., von Laer D., Rossi J. J., Trobridge G. D. Foamy combinatorial anti-HIV vectors with MGMTP140K potently inhibit HIV-1 and SHIV replication and mediate selection in vivo // Gene Ther.-2010.-17, N 1.-P. 37-49.

Received 26.07.11 